\title{
NILAI-NILAI BUDAYA DALAM NOVEL OJO DUMEH KARYA AGNES YANI SARDJONO
}

\section{CULTURAL VALUES IN THE NOVEL OJO DUMEH BY AGNES YANI SARDJONO}

\author{
Pondra Muliawan \\ Prodi Pendidikan Bahasa Indonesia \\ Pascasarjana Universitas Negeri Semarang \\ pondramuliawan93@gmail.com
}

\begin{abstract}
ABSTRAK
Tujuan dari penelitian ini adalah untuk mengetahui nilai-nilai budaya yang ada dalam novel "Ojo Dumeh" karya Agnes Yani Sardjono. Metode yang digunakan dalam penelitian ini adalah metode deskriptif kualitatif berdasarkan analisis isi. Analisis isi (content analysis) adalah penelitian yang bersifat pembahasan mendalam terhadap isi suatu informasi tertulis atau tercetak dengan membuat inferensi-inferensi yang dapat ditiru (repicable) dan sahih, dengan memperhatikan konteksnya. Objek atau sumber data dalam penelitian ini adalah novel "Ojo Dumeh" karya Agnes Yani Sardjono. Teknik kepustakaan adalah upaya yang dilakukan untuk mencari dan mengumpulkan bahan-bahan teori yang berkaitan dengan permasalahan yang akan dibahas dan dikembangkan oleh para ahli yang bersumber pada kepustakaan untuk mencapai tujuan penelitian. Sumber data karya ilmiah ini diambil dari novel "Ojo Dumeh" karya Agnes Yani Sardjono. Teknik analisis data yang digunakan dalam penelitian ini berdasakan pada analisis isi. Nilai-Nilai Budaya Pada Novel "Ojo Dumeh" Karya Agnes Yani Sardjono" yang masih melekat sampai saat ini, bahkan ajaran-ajaran tersebut merupakan bagian dari kekayaan bangsa Indonesia terhadap kebudayaan yang ada. Hal tersebut dapat diangkat sebagai sebuah seni dan pedoman kehidupan masyarakat yang dapat dipilih dan dipelajari yang mana yang baik maupun yang buruk. nilai-nilai budaya pada novel "Ojo Dumeh" karya Agnes Yani Sardjono" yang dituliskan yaitu kepercayaan dan sikap, nilai dan norma, proses mental dan belajar, rasa diri dan ruang lingkup dan hubungan dan kehidupan sosial.
\end{abstract}

Kata Kunci: nilai, budaya, novel

\begin{abstract}
The aim of this research is to know the cultural values in the novel "Ojo Dumeh" by Agnes Yani Sardjono. The methodology in this research used qualitative descriptive based on the content analysis. The content analysis was in the research discussed the writing content information or printing with created inferences that could be replicated and valid based on contexts. The object or source in this research was a novel "Ojo Dumeh" by Agnes Yani Sardjono. The literature technique was being done to seek and to collect theories which were related to the problems that would be discussed and developed by experts based on the literature for reaching the aim of the research. The source data that used in this research was taken a novel "Ojo Dumeh" by Agnes Yani Sardjono. The analysis technique data used in this research based on content analysis. The cultural values in the novel "Ojo Dumeh" by Agnes Yani Sardjono that is still attached until right now, even those teachings are part of Indonesia wealth toward cultural. The case could be taken as art and guider for community life that could be chosen and learned which gave kind perspective or cruel perspective. The cultural values in the novel "Ojo Dumeh" by Agnes Yani Sardjono that created namely beliefs and attitudes, values and norms, mental processes and learning, a sense of self and relationship and social life.
\end{abstract}

Keywords: Values, cultural, novel. 


\section{PENDAHULUAN}

Bahasa merupakan alat komunikasi yang paling efektif, yang dipakai oleh setiap masyarakat. Melalui bahasa, seseorang dapat menyampaikan informasi berupa idea, pikiran, pendapat, perasaan, serta pesan kepada orang lain. Begitu juga sebaliknya, seseorang dapat menerima informasi mahu pun pesan daripada orang lain melalui bahasa yang digunakan. Selain itu, bahasa memiliki peranan penting dalam rangka melakukan apresiasi terhadap karya seni sastra.

Menggunakan bahasa dalam rangka mengapresiasi karya sastra merupakan hal yang sangat perlu dilakukan oleh setiap pembaca terlebih pencinta karya seni sastra. Hal ini mendasarkan bahwa dengan menganalisis karya sastra pembaca atau penikmat sastra akan lebih memiliki pengetahuan dan kemampuan karya mengapresiasi sastra yang memadai. pembelajaran sastra setidaknya membantu seseorang atau seseorang dalam empat aspek, yakni membantu meningkatkan keterampilan berbahasa, meningkatkan pengetahuan budaya,mengembangkan cipta rasa dan menunjang pembentukan watak atau karakter, sebab karya sastra memiliki fungsi sebagai media etika (akhlak/moral) estetika (seni dan keindahan) dan pendidikan.

Sastra adalah hasil karya cipta manusia melalui idea-idea, imaginasi, pengalaman peribadi, orang tua, teman, saudara dan orang-orang di sekitar kita yang dituangkan lewat fikiran dan ditulis dalam sebuah buku dan menjadi sebuah karya yang dapat dinikmati oleh khalayak umum bukan hanya untuk diri sendiri.

Sumardjo dan Sumaini (1997:61) definisi sastra yaitu : 1) Sastra adalah seni bahasa, 2) Sastra adalah ungkapan spontan dari perasaan yangmendalam, 3) Sastra adalah ekspresi pikiran dalam bahasa 4) Sastra adalah inspirasi kehidupan yang dimateraikan dalamsebuah bentuk keindahan, 5) Sastra adalah semua buku yang memuat perasaankemanusiaan yang benar dan kebenaran moral dengan sentuhan kesucian, keluasan pandangan dan bentuk yang mempesona.

Selanjutnya Purwandari (2012:121) menjelaskan sastra adalah karya tulis yang jika dibandingkan dengan karya tulis orang lain, memiliki berbagai ciri dan keunggulan seperti keorisinilan, keartisikan, serta keindahan dalam isi dan ungkapannya. Ada tiga aspek yang harus ada dalam sastra, yaitu keindahan, kejujuran dan kebenaran. Kalau ada sastra yang mengorbankan salah satu aspek ini, misalnya karena alasan komersial, maka sastra itu kurang baik.

Novel merupakan salah satu dari karya sastra yang sering digunakan sebagai sarana pembelajaran dalam kehidupan sehari-hari, karena di dalam novel terdapat nilai-nilai yang terkandung di dalamnya. Selanjutnya Semi (1997:32) mengungkapkan bahwa novel adalah karya sastra yang mengungkapkan suatu kosentrasi kehidupan pada suatu saat yang tegang, dan pemusatan kehidupan yang tegas. Ungkapan tegang dan tegas mengindikasikan bahwa karya sastra novel akan menampakan sebuah kehidupan yang tegang dimana didalamnya memunculkan suatu masalah/ persoalan sebagai ide cerita, dan tegas disini dituliskan dalam bahasa yang sederhana dengan tujuan mudah dipahami. Sejalan dengan pendapat tersebut (Ratna, 2009:01) berpendapat bahwa novel adalah suatu cerita dengan alur panjang mengisi satu buku atau lebih, yang mengarang kehidupan manusia, yang bersifat imajinatif, menceritakan kehidupan manusia hingga terjadinya konflik yang dapat menyebabkan perubahan nasib. Senada dengan pendapat tersebut Wiyanto (2006:77) novel adalah cerita yang menampilkan suatu kejadian yang luar biasa pada kehidupan pelakunya, yang menyebabkan perubahan sikap hidup atau menentukan nasibnya.

Berdasarkan beberapa pendapat yang telah dikemukakan di atas, dapat penulis simpulkan bahawa novel adalah sebuah karya sastra yang bercerita tentang tokoh-tokoh dan kelakuan mereka dalam kehidupan sehari-hari, dengan menitik beratkan pada sisi-sisi yang aneh dari naratif tersebut, novel merupakan suatu bentuk tulisan yang berupa cerita prosa yang menceritakan kehidupan dan konflik-konflik yang dialami oleh manusia. Nilai-nilai yang terkandung dalam novel bermacammacam, mulai dari nilai agama, nilai sosial, nilai pendidikan, nilai moral, nilai budaya, dan lain-lain. Dari nilai-nilai yang terkandung dalam novel tersebut, pembaca dapat belajar memahami tentang arti kehidupan dalam masyarakat.

Salah satu pembelajaran sastra yang hendak dianalisis dalam penelitian ini adalah nilai budaya. Wicaksono (2014:287) mengatakan nilai budaya merupakan kesatuan dan keutuhan yang tidak terpisahkan dari hidup dan kehidupan manusia baik secara pribadi, sosial maupun religius. Dikatakan demikian karena berfungsinya pandangan dunia, mitologi, dan kosmologi suatu masyarakat ditentukan 
oleh dan bergantung pada nilai budaya. Hal ini menunjukkan bahwa nilai budaya berkedudukan dan berfungsi strategis dan vital bagi hidup dan kehidupan manusia dalam budaya apa pun baik sebagai pribadi, dan anggota masyarakat.

Pendapat berbeda disampaikan Pidarta (2013:167) nilai budaya adalah keseluruhan hasil manusia hidup bermasyarakat yang berisi aksi-aksi terhadap dan oleh sesama manusia sebagai anggota masyarakat yang merupakan kepandaian, kepercayaan, kesenian, moral, hukum, adat-istiadat, dan lainlain kepandaian. Nilai budaya merupakan salah satu nilai yang sering dijumpai dalam suatu karya sastra khususnya novel. Karya sastra mengandungi aspek-aspek kultural, bukan individual. Dari sebuah novel kita dapat mengetahui nilai-nilai budaya yang ada dalam masyarakat tertentu, baik budaya yang bersifat positif maupun budaya yang bersifat negatif. Dari sinilah penulis memanfaatkan novel sebagai sarana untuk pelestarian budaya serta menjaga budaya tersebut. Dalam menulis sebuah karya sastra, khususnya novel, pengarang novel sering menuangkan berbagai macam budaya yang ada di sekitarnya ke dalam tulisannya. budaya-budaya tersebut dapat berupa bahasa, adat istiadat, kebiasaan dan masih banyak lagi budaya yang lain untuk menjelaskan serta menggambarkan macam-macam budaya kepada pembaca. Novel yang banyak mengangkat dan membahas mengenai nilai budaya pada isi ceritanya ialah novel "Ojo Dumeh" karya Agnes Yani Sardjono.

Novel "Ojo Dumeh" karya Agnes Yani Sardjono diterbitkan tahun 1997 di Yogyakarta oleh Yayasan Pustaka Nusantara yang menceritakan tentang Samhudi seorang wartawan free lance, mendapat order menulis biografi Kusni Bakhtiar pengusaha muda yang sukses. Karena kesuksesannya itu Kusni Bakhtiar bercita-cita menjadi seorang lurah. Karena tugas dan profesinya itu, Samhudi lalu tinggal di Yogyakarta untuk menggarap biografi Kusni. Di Yogyakarta Samhudi bisa tahu liku dunia kriminalitas. Sebab pada tahun 80-an gali-gali di kota Gudeg memang malang melintang sebagai penguasa kota. Suatu hari Samhudi memperoleh informasi bahwa Kusni Bakhtiar ternyata tokoh kriminalitas yang diburu pihak berwajib. Dia di kelas sebagai pembunuh berdarah dingin. Tokoh perampok yang licin dan kejam. Tahun 1983 sepertinya masa kejayaan gali berakhir. Mereka diburu Petrus (penembak misterius). Termasuk Kusni Bakhtiar yang sudah lama diincar polisi. Dalam situasi kritis, Samhudi harus memilih menyelamatkan nyawa Kusni Bahtiar dengan resiko nyawanya sendiri terancam atau mengkhianati persahabatannya dengan menyerahkan Kusni Bakhtiar pada pihak yang berwajib. Samhudi bagai buah simalakama yang bingung untuk menentukan pilihan.

Alasan dipilihnya Novel "Ojo Dumeh" karya Agnes Yani Sardjono karena novel ini mempunyai keistimewaan dari segi isinya yang menceritakan tentang nilai-nilai budaya dalam kehidupan rakyat Indonesia. Nilai budaya yang disampaikan dalam novel ini dituliskan dalam sebuah bentuk karakter seseorang dalam kehidupan. Tingkat pemahaman dalam setiap ceritanya sulit untuk ditebak dan dideskripsikan. Salah satu nilai budaya bangsa Indonesia dalam ialah nilai kejujuran dan kebenaran. Kejujuran dalam bersikap dan mengungkapkan suatu kebenaran sangat penting dalam sebuah kehidupan, karena nilai tersebut merupakan nilai yang sangat sulit untuk diterapkan dalam diri seseorang.

Budaya dalam Novel "Ojo Dumeh" Karya Agnes Yani Sardjono" ini berhubungan erat dengan nilai-nilai pendidikan yang telah banyak diajarkan pada orangctua kita terdahulu diantaranya perilaku jujur terhadap segala hal yang merupakan pondasi awal mengenai kebaikan hati seseorang. Selain itu nilai budaya lainnya yang diajarkan dalam novel ini bersikap rendah hati dan tidak angkuh. Sikap rendah hati yang seperti yang diajarkan oleh orang tua kita akan membawa seseorang kedalam kenyamanan dan ketenteraman hidup, jalani hidup dengan apa adanya sesuai dengan kemampuan diri masing-masing dengan penuh keikhlasan. Untuk lebih spesifikasi nilai budaya dalam Novel "Ojo Dumeh" karya Agnes Yani Sardjono akan diuraikan sebagai berikut:

\section{- Hubungan Sosialisasi}

Budaya mengatur hubungan manusia dan hubungan lain berdasarkan usia, jenis kelamin, status, kekeluargaan, kekayaan, kekuasaan, dan kebijaksanaan.

- Nilai dan Norma

Nilai dan norma manusia juga dipengaruhi oleh kebutuhan hidup masing-masing. Seseorang yang menginginkan kelangsungan hidup, menghargai usaha-usaha pengumpulan makanan, penyediaan pakaian dan rumah yang memadai. Sedangkan mereka yang mempunyai kebutuhan lebih tinggi menghargai materi, uang, gelar-gelar pekerjaan, hukum, dan keteraturan. 
- Rasa diri dan ruang lingkup

Kenyamanan seseorang dengan dirinya dapat terlihat secara berbeda oleh budaya.

- Proses Mental dan Belajar

Setiap budaya mempunyai suatu proses berpikir, namun setiap budaya mewujudkan proses tersebut dengan cara yang berbeda. Kehidupan dalam suatu tempat tertentu menetapkan hukum-hukum untuk mempelajari atau tidak informasi tertentu, dan ini ditegaskan dan diperkuat oleh budaya di sana.

- Kepercayaan dan Sikap

Dalam semua budaya tampaknya orang-orang mempunyai perhatian terhadap hal-hal supernatural yang jelas dalam agama-agama dan praktik-praktik agama mereka. Agama dipengaruhi oleh budaya dan budaya pun dipengaruhi oleh agama. Sistem kepercayaan agama sekelompok orang agak bergantung pada tingkat perkembangan kemanusiaan mereka.

Berdasarkan uraian latar belakang di atas penulis akan melaksanakan penelitian dengan menganalisis nilai budaya sebuah novel yang diberi judul "Nilai-Nilai Budaya Pada Novel "Ojo Dumeh" Karya Agnes Yani Sardjono"

\section{METODE PENELITIAN}

Tujuan penelitian ini adalah mendeskripsikan nilai-nilai budaya yang terkandung dalam novel "Ojo Dumeh" karya Agnes Yani Sardjono. Maka dari itu, perlu digunakan suatu metode untuk mencapai tujuan tersebut. Metode yang digunakan dalam penelitian ini adalah metode deskriptif kualitatif berdasarkan analisis isi. Analisis isi (content analysis) adalah penelitian yang bersifat pembahasan mendalam terhadap isi suatu informasi tertulis atau tercetak dengan membuat inferensi-inferensi yang dapat ditiru (repicable) dan sahih, dengan memperhatikan konteksnya. Model analisis isi bukan hanya mengetahui bagaimana isi teks, tetapi bagaimana pesan itu disampaikan hingga bisa melihat makna yang tersembunyi dari suatu kajian yang diteliti. Objek atau sumber data dalam penelitian ini adalah novel "Ojo Dumeh" karya Agnes Yani Sardjono. Teknik kepustakaan adalah upaya yang dilakukan untuk mencari dan mengumpulkan bahan-bahan teori yang berkaitan dengan permasalahan yang akan dibahas dan dikembangkan oleh para ahli yang bersumber pada kepustakaan untuk mencapai tujuan penelitian. Sumber data karya ilmiah ini diambil dari novel "Ojo Dumeh" karya Agnes Yani Sardjono.

\section{HASIL DAN PEMBAHASAN}

\section{Temuan Penelitian Nilai-Nilai Budaya Pada Novel "Ojo Dumeh" Karya Agnes Yani Sardjono"}

Nilai budaya merupakan salah satu nilai yang sering dijumpai dalam suatu karya sastra khususnya novel. Karya sastra mengandungi aspek-aspek kultural, bukan individual. Dari sebuah novel kita dapat mengetahui nilai-nilai budaya yang ada dalam masyarakat tertentu, baik budaya yang bersifat positif maupun budaya yang bersifat negatif. Dari sinilah penulis memanfaatkan novel sebagai sarana untuk pelestarian budaya serta menjaga budaya tersebut. Dalam menulis sebuah karya sastra, khususnya novel, pengarang novel sering menuangkan berbagai macam budaya yang ada di sekitarnya ke dalam tulisannya. Budaya-budaya tersebut dapat berupa bahasa, adat istiadat, kebiasaan dan masih banyak lagi budaya yang lain untuk menjelaskan serta menggambarkan macam-macam budaya kepada pembaca. Berikut ini akan dideskripsikan temuan penelitian mengenai "nilai-nilai budaya pada novel "Ojo Dumeh" Karya Agnes Yani Sardjono":

\section{Kepercayaan dan Sikap}

Dalam semua budaya tampaknya orang-orang mempunyai perhatian terhadap hal-hal supernatural yang jelas dalam agama-agama dan praktik-praktik agama mereka. Agama dipengaruhi oleh budaya dan 
budaya pun dipengaruhi oleh agama. Sistem kepercayaan agama sekelompok orang agak bergantung pada tingkat perkembangan kemanusiaan mereka. Tapi biasanya gak semua orang beranggapan bahwa suatu kebudayaan dengan kebudayaan lain dapat menimbulkan konflik. Karena konflik tersebut akan terjadi apabila terjadi perbedaan kepercayaan. Lain halnya dengan yang memiliki persamaan kepercayaan. Jika suatu kebudayaan dan kebudayaan lainnya memiliki kepercayaan yang sama, bukan tidak mungkin kedua kebudayaan tersebut akan menimbulkan suatu akulturasi dan bahkan pula akan menimbulkan asimilasi antara kedua kebudayaan tersebut. Yang dimaksud dengan akulturasi disini yakni perpaduan antara suatu budaya dengan budaya lainnya sehingga dapat menimbulkan kebudayaan yang masih ada unsur-unsur kedua budaya tadi yang masih melekat.

\title{
Temuan nilai budaya pada Aspek Kepercayaan dan Sikap (Data 1)
}

\begin{abstract}
"Belum pernah terdengar Kali Winongo memakan korban manusia. Maka itu orang menyebut sebagai kali wedok. Kali perempuan, aneh. Ada kali laki-laki, ada kali perempuan. Yang lakilaki biasanya ganas. Sering makan korban manusia. Apa begitu ya tabiat laki-laki? Lebih suka mencari mangsa daripada menunggu menjadi mangsa betina.
\end{abstract}

(Novel “Ojo Dumeh” Karya Agnes Yani Sardjono” Hal 1-2)

\section{Deskripsi (data 1)}

Cerita pada kutipan tersebut menggambarkan bahwa masih terdapat kebudayaan yang kental mengenai kepercayaan adanya kali yang ditakuti karena sering memakan korban manusia. Hal ini terjadi karena nilai-nilai budaya zaman dahulu masih sering diceritakan dan disangkutpautkan dengan kehidupan zaman sekarang. Sehingga orang beranggapan bahwa kali tersebut benar-benar tempat tinggal sebuah mahluk halus yang ditakutkan, hingga sampai sekarang ini. Nilai-nilai budaya terhadap kepercayaan inilah yang secara tidak langsung menjadi sebuah kepercayaan seseorang dari cerita yang disampaikan.

\section{Temuan nilai budaya pada Aspek Kepercayaan dan Sikap (Data 2)}

\author{
"dan, kamu tahu arti gunung merapi bagi sebagian masyarakat Jogja?" \\ Gunung itupun dianggap sebuah Kraton. Kraton mahluk halus. \\ "Dengan penguasa Eyang Permadi dibantu Eyang Sapu Jagat, Eyang Merapi, Eyang Petruk dan \\ seorang penguasa Putri, yakni Eyang Gadung Melati. Kau Percaya?" \\ “Aku tertawa, "Mas Kusni percaya?"Balasku. \\ "Kalau kamu tidak percaya, saya maklum. Karena kamu bukan warga kota ini. Tapi sebagai \\ warga Kraton Ngayodyakarto Hadiningrat, saya harus percaya mas. Meski kepercayaan itu \\ kadarnya lain disbanding para orangtua. Lebih-lebih orangtua produk lama dan masih dekat- \\ dekat dengan Kraton. Kepercayaan mereka sangat kental”
}

(Novel “Ojo Dumeh” Karya Agnes Yani Sardjono” Hal 110-111)

\section{Deskripsi}

Kata kebudayaan mengingatkan kita dengan sebuah adat istiadat dan kepercayaan nenek moyang terdahulu terhadap sesuatu yang bersifat gaib. Hal ini berkaitan dengan kejadian-kejadian yang janggal dan sering ditemui di sekitar kita. Sama halnya pada masyarakat Jawa Kraton mengenai kepercayaan terhadap gunung merapi yang dihuni oleh bangsa golongan mahluk halus. Hal ini merupakan bagian dari kelestarian kebudayaan yang ada di Indonesia. Sistem kepercayaan pada masyarakat Indonesia sudah ada sejak masyarakat berburu dan mengumpulkan makanan. Pada masa itu sudah mengenal adanya penghormatan terhadap orang yang sudah meninggal dengan cara menguburkan orang yang sudah meninggal di gua-gua. Adanya pandangan, hidup tidak akan berhenti setelah orang meninggal. Orang yang meninggal akan pergi ke suatu tempat yang lebih baik. Orang yang sudah meninggal masih dapat dihubungi oleh orang yang masih hidup di dunia ini demikian pula sebaliknya. Jika yang 
meninggal orang yang berpengaruh maka diusahakan akan selalu ada hubungan untuk dimintai nasehat/ perlindungan bila ada kesulitan dalam kehidupan di dunia.

\title{
Temuan nilai budaya pada Aspek Kepercayaan dan Sikap (Data 3)
}

\begin{abstract}
"Mungkin tahun 1969, Kali Code banjir lahar. Dahsyat, banyak rumah penduduk yang tenggelam dan terkubur lahar dingin. Lalu Ngarso Dalem Sultan Hemengku Buwonoo IX Rawuh ke Yogya. Apa yang beliau lakukan? Ngarso Dalem hanya turun Code. Membasuh kedua tangan dan kaki. Seketika banjir reda. Meski hujan turun berhari-hari, banjir Code tidak lagi memakan korban"
\end{abstract}

(Novel “Ojo Dumeh” Karya Agnes Yani Sardjono” Hal 111)

\section{Deskripsi}

Kepercayaan adat istiadat masyarakat, terutama di Pulau jawa hingga saat ini masih sangat kuat diantaranya orang-orang yang memiliki keturunan dari bangsawan yang memiliki mitos sebuah kekuatan gaib. Sama halnya yang terjadi pada kutipan di atas Sultan Hemengku Buwono diyakini memiliki hubungan gaib dengan penunggu alam yang sedang marah. Namun, hal ini hanya sebagian dari kekuasaan Allah SWT yang telah dibuktikan melalui kejadian tersebut. Kepercayaan ini berdasarkan pengalaman-pengalaman dari masyarakat. Pola pikir manusia berkembang. Manusia mulai berpikir tentang apa yang dialaminya. Pertanyaan yang muncul hingga pada kesimpulan bahwa di luar dirinya ada suatu kekuatan yang makin besar dan yang tidak ditandingi oleh kekuatan manusia. Kekuatan itu adalah kekuatan dari Tuhan Yang Maha Esa. Manusia percaya bahwa Tuhan Yang Maha Esa adalah pencipta alam semesta beserta isinya. Oleh karena itu, manusia wajib melestarikan alam semesta agar dapat memenuhi kebutuhan hidupannya, atau menjaga keseimbangan alam semesta agar dapat menjadi tumpuan hidup manusia.

\section{Nilai dan Norma}

Nilai dan norma manusia juga dipengaruhi oleh kebutuhan hidup masing-masing. Seseorang yang menginginkan kelangsungan hidup, menghargai usaha-usaha pengumpulan makanan, penyediaan pakaian dan rumah yang memadai. Sedangkan mereka yang mempunyai kebutuhan lebih tinggi menghargai materi, uang, gelar-gelar pekerjaan, hukum, dan keteraturan. Dalam kehidupan sehari-hari manusia dalam berinteraksi dipandu oleh nilai-nilai dan dibatasi oleh norma-norma dalam kehidupan sosial. Norma dan nilai pada awalnya lahir tidak disengaja, karena kebutuhan manusia sebagai makluk sosial dan harus berinteraksi dengan yang lain menuntut adanya suatu pedoman, pedoman itu lama kelamaan norma-norma tersebut dibuat secara sadar.

\section{Temuan nilai budaya pada aspek nilai dan norma (data 1)}

"Seorang anak yang telah dipasung hampir tiga tahun oleh orang tuanya diselamatkan. Anak tersebut tidak gila atau sakit jiwa. Dia hiperaktif. Terlalu cerdas bagi anak-anak sebaya. Oleh kedua orang tuanya yang buta huruf, malah dianggap gila.

(Novel “Ojo Dumeh” Karya Agnes Yani Sardjono” Hal 65)

\section{Deskripsi}

Kutipan di atas menyatakan bahwa sebaik-baiknya orangtua janganlah mendidik anak dengan cara yang kurang baik, hal ini dapat merusak pemikiran anak dan keterampilan anak secara dini. Cerita tersebut menggambarkan nilai dan norma pada kehidupan masyarakat yang kurang memiliki pendidikan yang baik. Sehingga menganggap bahwa anaknya sendiri gila. Pada anak tersebut merupakan anak yang hiperaktif (terlalu cerdas). Dengan bimbingan dan pengarahan yang baik, anak tersebut akan lebih 
mudah mendapatkan pendidikan dan dapat meningkatkan keterampilannya dalam berbagai hal, bukan dengan cara di pasung yang dapat merusak masa depannya.

\section{Proses Mental dan Belajar}

Setiap budaya mempunyai suatu proses berpikir, namun setiap budaya mewujudkan proses tersebut dengan cara yang berbeda. Kehidupan dalam suatu tempat tertentu menetapkan hukum-hukum untuk mempelajari atau tidak informasi tertentu, dan ini ditegaskan dan diperkuat oleh budaya di sana. Belajar merupakan proses mental dan emosional atau proses berpikir dan merasakan. Seseorang dikatakan belajar bila pikiran dan perasaannya aktif. Aktivitas pikiran dan perasaan itu sendiri tidak dapat diamati orang lain, akan tetapi terasa oleh yang bersangkutan (orang yang sedang belajar itu) terhadap nilainilai kehidupan yang sedang dijalani.

\section{Temuan nilai budaya pada aspek proses mental dan belajar (Data 1)}

"saya masih ingat, kalau perut saya lapar, saya sering makan gaplek mentah tadi. Rasanya pahit. Tapi saya harus makan, karena lapar sekali.

(Novel “Ojo Dumeh” Karya Agnes Yani Sardjono” Hal 4)

\section{Dekripsi}

Pada cerita yang ditampilkan dalam kutipan di atas menceritakan bahwa seseorang yang berpikir untuk menghilangkan rasa lapar yang ia miliki dengan berbagai cara. Hal ini sangat lumrah dilakukan mengingat apa yang menjadi menjadi kebiasaan seseorang pada daerah tertentu sangat dipengaruhi oleh keadaan lingkungan yang ada. Hal ini merupakan salah satu jenis nilai budaya pada masyarakat yang masih mengkonsumsi beberapa makanan tradisional seperti gaplek (salah satu makanan yang terbuat dari singkong).

\section{Temuan nilai budaya pada aspek proses mental dan belajar (Data 2)}

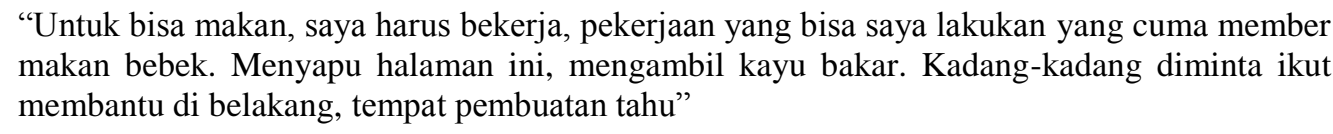

\section{Dekripsi}

(Novel “Ojo Dumeh” Karya Agnes Yani Sardjono” Hal 4)

Pada pembahasan di atas diketahui bahwa seseorang masih dalam proses mental untuk bisa bertahan hidup. Dengan bekerja keras maka akan menghasilkan suatu nilai-nilai keberhasilan pada suatu tujuan tertentu. Hal ini terlihat pada kebiasaan orang zaman dahulu yang bisa bekerja hanya untuk mencari makan dan bertahan hidup. Namun, nilai budaya seperti masih sangat jarang ditemui di masyarakat moden. Kebanyak dari masyarakat kota tidak banyak melakukan aktivitas yang berbeda dari pekerjaannya sehari-hari. Hanya terfokus pada satu pekerjaan yang digeluti. Sehingga tingkat keterampilan yang dimiliki hanya terbatas pada kemampuan ia bekerja di tempat tertentu.

\section{Temuan nilai budaya pada aspek proses mental dan belajar (data 3)}

"Dia hidup dijalanan, dari kota satu ke kota lainnya."

"bekerja apa saja asal bisa untuk hidup."

"sampai akhirnya di bisa jadi pengusaha penggergajian kayu di Palembang, punya kebun kelapa sawit yang cukup luas di Jambi. Dagang kayu dari Kalimantan ke Jawa. Jual-beli mobil. Dia cukup sukses."

(Novel “Ojo Dumeh” Karya Agnes Yani Sardjono” Hal 20-2 


\section{Dekripsi}

Kutipan di atas mengandung nilai budaya yang mengajarkan kita bahwa sesorang untuk bertahan hidup harus bekerja keras melalui proses mental yang baik dan belajar untuk selalu sukses. Kerja keras artinya melakukan suatu usaha atau pekerjaan secara terus menerus tanpa mengenal lelah. Kerja keras juga dapat diartikan suatu tindakan atau perbuatan yang dilakukan dengan sungguh-sungguh dan serius sampai tercapai suatu tujuan. Agama Islam mengajarkan umatnya agar selalu bekerja keras dalam menjalankan kehidupannya di muka bumi ini. Segala sesuatu yang dilakukan tidak dengan kerja keras, hasilnya tidak akan sempurna. Sebaliknya, seberat apa pun suatu pekerjaan jika dilakukan dengan sungguh-sungguh, nescaya hasilnya akan dapat diraih dengan baik.

\section{Rasa diri dan ruang lingkup}

Kenyamanan seseorang dengan dirinya dapat terlihat secara berbeda oleh seseorang dalam sebuah budaya. Nilai rasa diri merupakan bagian dari pencitraan seseorang terhadap sesuatu yang dimilikinya. Kadang terlihat berlebih-lebihan, terkadang terlihat hanya sementara terhadap sesuatu yang diingikan dan dimiliki, namun jarang terlihat pada orang lain.

\section{Temuan nilai budaya pada aspek rasa diri dan ruang lingkup (data 1)}

"Yogya, kota tua dan kecil, gambaran dari denyut kehidupan yang anyem. Pukul sembilan malam lalu lintas mulai sepi. Hanya tempat-tempat tertentu masih berdenyut agak kencang."

(Novel “Ojo Dumeh” Karya Agnes Yani Sardjono” Hal 37)

\section{Deskripsi}

Pernyataan di atas menyatakan budaya pada kehidupan Kota Jogja yang masih tentram. Pada malam hari suasana hening menyelimuti kota yang masih hidup dengan kehidupan sosial yang baik. Bahkan hanya beberapa tempat saja yang masih beraktivitas. Selebihnya Jogja merupakan tempat yang baik untuk dijadikan panutan mengingat kehidupan masyarakatnya yang belum terisolasi dari dunia luar dan kehidupan negatif zaman moden.

\section{Hubungan dan Kehidupan Sosial}

Budaya mengatur hubungan manusia dan hubungan lain berdasarkan usia, jenis kelamin, status, kekeluargaan, kekayaan, kekuasaan, dan kebijaksanaan. Sosialisasi adalah proses mempelajari dan menanamkan suatu nilai, norma, peran, dan pola perilaku dari satu generasi ke generasi lain dalam sebuah kelompok atau masyarakat agar dapat berpartisipasi dalam kehidupan bermasyarakat. Beberapa sosiolog menyebut sosialisasi sebagai teori mengenai peranan karena dalam proses sosialisasi diajarkan peran-peran yang harus dijalankan oleh individu. Seorang dikatakan telah melakukan sosialisasi dengan baik, apabila ia bukan hanya menampilkan kebutuhannya sendiri saja, tetapi juga memerhatikan kepentingan dan tuntutan orang lain. Proses pembelajaran berlangsung secara bertahap, perlahan tapi pasti dan berkesinambungan. Pada awalnya, proses itu berlangsung dalam lingkungan keluarga, kemudian berlanjut pada lingkungan sekitarnya, yaitu lingkungan tetangga, kampung, kota, hingga lingkungan negara dan dunia. Di samping itu, individu mengalami proses enkulturasi (pembudayaan), yaitu individu mempelajari dan menyesuaikan alam pikiran dan sikapnya dengan adat istiadat, sistem norma, dan peraturan yang berlaku dalam kebudayaan masyarakatnya. 


\title{
Temuan nilai budaya pada aspek hubungan dan kehidupan sosial (Data 1)
}

\author{
"Banyak orang tidak senang dengan tabiat Pak Carik," ujar Dirun, buruh Tani yang dipercaya \\ menunggu rumah Kusni di Kali Ijo."Benar lho mas, dia orangnya pelit. Tapi sombongnya \\ setengah mati. Lupa dengan asal-usulnya.
}

(Novel “Ojo Dumeh” Karya Agnes Yani Sardjono” Hal 43)

\section{Deskripsi}

Membina hubungan yang baik antar sesama manusia merupakan suatu hal yang penting dilakukan oleh setiap orang. Begitu pentingnya membina hubungan yang baik ini, karena kita merupakan makhluk sosial yang tidak mungkin dapat dan mampu hidup sendirian tanpa bantuan orang lain. Ada beberapa cara untuk membina hubungan yang baik yang berlaku untuk umum dalam kehidupan sehari-hari.

Pada dasarnya semua orang ingin dihargai, tidak peduli apakah ia orang berpangkat atau tidak, orang miskin atau kaya, sesama agama atau tidak seagama, sesama suku atau tidak sesama suku, semuanya ingin dihargai secara proporsional. Namun sayangnya, banyak orang dikalangan kita yang tidak mau menghargai orang lain. Padahal menghargai orang lain bukan berarti memberikan sesuatu yang besar nilainya. Misalnya saja menghargai pendapat orang lain. Hal ini sangat penting dilakukan dalam membina hubungan yang baik. Kalau kita tidak mau menghargai orang lain, jangan berharap orang lain akan mau menghargai kita.Setiap orang selalu ingin dihormati. Oleh karena itu, janganlah kita menghormati orang lain karena ia kebetulan punya pangkat atau kedudukan. Kita perlu menghormati orang lain, bila kita melihat orang lain tersebut melakukan sesuatu yang baik. Kita juga perlu menghormati orang yang lebih atau lebih maju dari kita. Atau dengan kata lain, ciptakan suasana saling menghormati di antara kita.

\section{Temuan nilai budaya pada aspek hubungan dan kehidupan sosial (Data 2)}

\begin{abstract}
"Wuah, untuk Mas Kusni, saya kira kok ada harapan. Kalau nanti dia maju dalam pemilihan Lurah, dia bisa menang. Banyak orang yang suka padanya. Dia banyak membantu kepentingan masyarakat Kelurahan. Dua bulan yang lalu Mas Kusni membantu pembangunan mushola. Untuk para pemudanya dibelikan 25 bola voli. Klub sepakbola di bina, dibelikan kaos team. Ikut membantu membangun jembatan yang ambruk. Duitnya banyak, tapi tidak pelit. Orangorang pada suka.
\end{abstract}

(Novel “Ojo Dumeh” Karya Agnes Yani Sardjono” Hal 9)

\section{Deskripsi}

Nilai budaya yang ditampilkan di atas yaitu berhubungan dengan nilai kebaikan dalam kehidupan masyarakat sejak zaman dahulu hingga sekarang. Salah satunya dengan menanamkan sikap ataupun kebiasaan sosialisasi dalam kehidupan bermasyarakat. Rasa sosialisasi dalam masyarakat merupakan proses pembelajaran seseorang untuk mempelajari pola hidup sesuai nilai, norma dan kebiasaan yang ada dijalankannya dalam masyarakat atau kelompok di mana dia berada. Unsur-unsur sosialisasi adalah peranan pola hidup dalam masyarakat sesuai nilai, norma, dan kebiasaan masyarakat. Sosialisasi peran yang sangat penting dalam proses pembelajaran yang dapat dilihat dari fungsi sosialisasi dan tujuan sosialisasi. Berdasarkan kutipan di atas dapat diketahui bahwa beberapa tujuan sosialisasi yaitu mampu mempelajari dan menghayati norma-norma yang ada dalam kelompok tempat ia tinggal, dapat mengenal masyarakat lebih luas, mengetahui peran-peran yang dimiliki masing-masing anggota masyarakat, dapat mengembangkan kemampuan sesuai peranan dan status sosialnya. 


\title{
Temuan nilai budaya pada aspek hubungan dan kehidupan sosial (Data 3)
}

\begin{abstract}
"Dimataku Kusni Bahtiar atau Kawit Budiman tetap seorang sahabat. Aku melihat sisi kemanusiaannya. Dia tak segan-segan menolong sesamanya yang menderita. Memberi bantuan di berbagai tempat tanpa pamrih apapun kecuali untuk memuaskan hatinya, dan setahuku, dia tak pernah melukai orang lain. Meski juga tak mudah baginya memaafkan orang-orang yang pernah menorehkan luka di hatinya.
\end{abstract}

(Novel “Ojo Dumeh” Karya Agnes Yani Sardjono” Hal 258)

\section{Deskripsi}

Nilai budaya dalam cerita di atas menyatakan bahwa janganlah menilai seseorang dari luarnya saja. Jangan menilai seseorang dari sampul atau penampilan luarnya saja. Hanya karena penampilan yang terkesan liar, punya kebiasaan buruk bukan berarti kita seenaknya saja menilai dan menghakimi orang . Mereka mungkin tampak kasar dan keras diluar, tapi mereka mungkin baik dan sensitif didalam, seperti buku tidak seharusnya dinilai dari sampul mereka, tapi apa yang ada didalamnya. Untuk mendapat predikat baik, tidak harus menjadi seperti yang orang mau. Kita harus menjadi diri sendiri, bukan purapura menjadi orang lain agar bisa diterima masyarakat. Jangan mudah dimanipulasi oleh penampilan, apa yang kita anggap baik belum tentu bagus dimata Tuhan. Orang yang kita nilai rendah ilmu dan kedudukannya, bisa jadi malah tinggi dalam pandangan Allah. Jadi, jangan biarkan orang lain menilai anda sekehendak hati, jangan pula terburu-buru sibuk berprasangka. Bukankah ada saat dimana diri kita dinilai rendah oleh orang lain, semua dipergilirkan. Bila saat ini masyarakat masih menilai kita sebagai orang baik-baik, Yakinlah, ada saatnya Allah membuka aib hambaNya dengan caranya sendiri. Mari belajar intropeksi diri, sebelum menghakimi orang lain, belajar perbaiki diri agar tidak menimbulkan prasangka.

\section{KESIMPULAN}

Setelah diadakan analisis novel, pembahasan terdapat Nilai-Nilai Budaya Pada Novel "Ojo Dumeh" karya Agnes Yani Sarjono yang masih melekat sampai saat ini, bahkan ajaran-ajaran tersebut merupakan bagian dari kekayaan bangsa Indonesia terhadap kebudayaan yang ada. Hal tersebut dapat diangkat sebagai sebuah seni dan pedoman kehidupan masyarakat yang dapat dipilih dan dipelajari yang mana yang baik maupun yang buruk. Nilai-Nilai budaya pada Novel "Ojo Dumeh" karya Agnes Yani Sarjono yang dituliskan yaitu: kepercayaan dan sikap, nilai dan norma, proses mental dan belajar, rasa diri dan ruang lingkup, hubungan dan kehidupan sosial.

\section{DAFTAR PUSTAKA}

Pidarta. (2013). Landasan Kependidikan. Jakarta: Rineka Cipta.

Purwandari, Retno. (2012). Buku Pintar Bahasa Indonesia. Yogyakarta: Familia.

Ratna, Nyoman. (2009). Teori, Metode, dan Teknik Penelitian. Sastra. Yogyakarta: Pustaka Pelajar.

Semi, Atar. (1997). Metode Penelitian Sastra. Bandung: Angkasa

Sudarmaji. (2014). Pedoman Penulisan Karya Ilmiah. STKIP-PGRI Bandar Lampung

Sumardjo, Jakob dan Sumaini. (1997). Apresiasi Kesusastraan. Jakarta : PT. Gramedia

Wicaksono, Andri. (2014). Pengkajian Prosa Fiksi. Yogyakarta : Garudhawaca.

Wiyanto, Asul. (2006). Kesusastraan Sekolah. Jakarta: Gramedia. 